\title{
Major Differences Between the Set of Rules of Accounting and Fiscal Policies in Albania
}

\author{
Ilva Isa \\ "Aleksander Xhuvani University" Elbasan, Albania
}

\begin{abstract}
Studying and interacting in dynamic and unstable economic environments of transitory post dictatorial economies makes every previous theory and previous study very often controversial. In this study we aim to bring a comparison between the set of accounting rules and fiscal policies. A specific focus will be on the most used and most practiced terms and voices, without making apart other parts that we rarely find in such economies. The importance of taxes and fiscal policies in non stable economies is a vital factor for the enhancement of the economy and the social development of the entire society. The information will be acquired through a mixed methodology: searching for information in literature, gathering of information from responsible authorities and interviewing key information specialists. This mixed methodology allows to obtain a deeper set of insights into this issue. Interviews were done with three auditors and other five chartered accountants, employed in private and public sector or were partners in large consulting practice
\end{abstract}

Keywords: Major differences between the set of rules of accounting and fiscal policies in Albania.

The general concern was toward the taxation and how the move toward IFRSs would change the calculation of taxable income.

\section{Methodology}

The information was gathered through a mixed methodology: searching for information in literature, gathering of information from responsible authorities and interviewing key information specialists. This mixed methodology allows to obtain a deeper set of insights into this issue.

Interviews were done with three auditors and other five chartered accountants, employed in private and public sector or were partners in large consulting practice.

The results of the findings are provided next:

The general concern was toward the taxation and how the move toward IFRSs would change the calculation of taxable income.

\section{Summary of differences between two sets of rules}

\section{Assets- Property, plant and equipment}

IFRSs: Must be estimated by reporting entity: Revaluation; Amortization, depreciation and depletion; Useful life.

Albanian tax rules: The rate of amortization, depreciation is determined by tax law.

\section{Assets - Intangible assets.}

IFRSs: Must be estimated by reporting entity; Useful life; Amortization; Revaluation

Albanian tax rules: The rate of amortization is $15 \%$, based on straight- line method. Revaluation not permitted for tax 
purposes.

\section{Goodwill}

IFRSs: To be tested for impairment;

Albanian tax rules: Capitalized and amortized $15 \%$ based on straight -line method.

\section{Grants}

IFRSs: Revenue based grants are deferred and matched as expense incurred. Capital grants are amortized as depreciation is recognized.

Albanian tax rules: Revenue is recognized when there is right to receive income upon the earlier of the income being due, paid and earned.

\section{Impairments}

IFRSs: IAS 16 and IAS 38 permit fixed assets and certain intangible assets to be carried at revalued amount.

Albanian tax rules: Impairment losses are not permitted for tax purposes.

\section{Inventory}

IFRSs: Valuation of inventories of goods could be: FIFO \& Average cost; The inventory is stated at the lower cost or net realizable value LCM.

Albanian tax rules: Impairment losses are not permitted for tax purposes.

\section{Profit tax}

IFRSs: When certain conditions are met, a deferred tax is recognized and displayed as noncurrent in balance sheet.

Albanian tax rules: The amount reported is the tax payable to tax authorities. Some expenses may not be allowable for tax purposes.

\section{Revenue from Construction Contracts}

IFRSs: Use of method of percentage of completion is required. When the final outcome cannot be estimated reliably, a zero-profit method is utilized.

Albanian tax rules: Revenue is recognized when there is right to receive income upon the earlier of the income being due, paid or earned.

The judgment of main areas of differences between two sets of rules is due to the recognition and the measurement criteria. The calculation of taxable profit begins with the profit calculated according to financial reporting rules. The professional accountants believed that the move toward IFRSs will increase the number and the type of adjustments needed to move from calculating accounting profit to the taxable profit.

Because of the large number of adjustments needed to be done, and the niche spaces there can be subjective profits. Maybe that is the reason that accountants spend a lot of time dealing with tax officers to settle their tax liabilities.

Tax liabilities are not the only factor that will change due to the changes of the accounting principles, other changes that will happen in a considerable way are also the financial statements analysis figures such as debt/equity ratio, the return on assets ratio etc.

The changes of the information in financial ration raises other question that will be treated below during the study. 
Accounting is a discipline that tries to set a static emphasis in the immense and unstoppable dynamism of economy.

One of the most difficult topics to deal with is fair value application and its acceptance with taxation. Mainly IFRSs principles are oriented toward the interest of reporting for investors, and the application of the fair value is applied almost to every principle.

The tax system constructed at a rule basis, because the tax administration and tax officers are there to guarantee the fiscal right of the State including so historic cost accounting, which is compared to fair value. The lack of adequate economic infrastructures in the country leads to difficulties in the application and measurement of fair value.

Theoretically, taxation depends on financial reporting, but at the actual state in Albania it is just the opposite. Because the noncompliance of tax regulations usually results in severe tax penalties and poor IFRSs monitoring mechanisms, most accountants choose to follow tax rules for reporting purposes. For example the valuation of assets is likely determined by taxation, leading to amounts reported on the balance sheet beneath the amounts according to IFRSs.

Accounting and taxation in Albania have come a long way, while experiencing most of the general and specific problems arising for transitional economies. The fact is that the requirements of the tax authorities for accounting information continue to predominate over those of other participants in market activities, such as creditors and investors.

Market operators are mainly concerned about the use of fair value accounting and about the subjectivity of profits under IFRSs reporting.

One of the biggest difficulties in Albania come form the fact that there is little knowledge from the tax authorities over fair value and their reporting and monitoring mechanisms are poor an inexperienced and they do not know how to deal with it.

From the interviews done it was stated that there exist different and sometime opponent opinions about the potential similarities and differences between accounting and taxation.

other aspects of IFRSs and taxation may be thought to be crucial to examine in order to make conclusions about this matter. The relationship between two sets of rules could be improved by:

1) clear guidelines on how to calculate income taxes, simple and explicit; 2) improved accounting disclosure requirements; and

3) continuous training of accountants and tax officials.

The aim of the examinations of the relationship between accounting and taxation is to provide insights for national regulators and policy makers to evaluate the feasibility of any (partial) alignment objective and to make better informed policy decisions. Although there have been major changes in tax accounting and other regulations, the researchers have not fully explored the outcomes and implications of these numerous regulatory and enforcement changes. This area offer interesting setting for future studies.

\section{References}

[1] http://www.financa.gov.al/al/raportime/programimi-ekonomiko-fiskal

[2] http://www.acca.com

[3] http://www.kkk.gov.al/faqe.php?id=1\&l2=135\&gj=sh 